\title{
Guideline for the description of soils in the Berlin metropolitan area: an extension for surveying and mapping anthropogenic and natural soils in urban environments within the German soil classification system
}

\author{
Mohsen Makki $^{1}$ (D) $\cdot$ Kolja Thestorf $^{1} \cdot$ Sabine Hilbert ${ }^{2} \cdot$ Michael Thelemann $^{2} \cdot$ Lutz Makowsky $^{3}$
}

Received: 31 December 2019 / Accepted: 4 November 2020 / Published online: 25 November 2020

(C) The Author(s) 2020

\begin{abstract}
Purpose In urban areas, humans shape the surface, (re-)deposit natural or technogenic material, and thus become the dominant soil formation factor. The 2015 edition of the World Reference Base for Soil Resources (WRB) describes anthropogenic urban soils as Anthrosols or Technosols, but the methodological approaches and classification criteria of national soil classification systems are rather inconsistent. Stringent criteria for describing and mapping anthropogenic soils in urban areas and their application are still lacking, although more than half (53\%) of the urban soils in Berlin are built-up by or contain anthropogenic material.

Materials and methods On behalf of the Berlin Senate Department for the Environment, Transport and Climate Protection and in close cooperation with the German Working Group for Urban Soils, a comprehensive guideline for soil description in the Berlin metropolitan area (BMA), with special regard to anthropogenic/technogenic parent material and anthropogenic soils, has been developed. Our approach includes all previous standard works for soil description and mapping and is based on studies that have been conducted in the BMA over the last five decades. Special emphasis was placed on the integration of our manual into the classification system of the German soil mapping guideline (KA5).

Results and discussion The extension of existing data fields (e.g., the further subdivision of land use types) as well as the creation of new data fields (e.g., pH value) adapted to the requirements of urban soil mapping has been carried out. Additional technogenic materials that occur in urban environments have been added to the list of anthropogenic parent materials. Furthermore, we designed appendices that clearly characterize typical soil profiles of the BMA and depict technogenic materials, their physical and chemical characteristics, as well as their origin and distribution. Our approach will set new benchmarks for soil description and mapping in urban environments, which will improve the quality of urban soil research in the BMA. It is expected that our approach will provide baselines for urban soil mapping in other metropolitan areas.

Conclusions Our guideline is a comprehensive manual for the description of urban soils within a national soil classification system. This mapping guideline will be the future standard work for soil surveys and soil mapping in the federal state of Berlin. Currently, representatives from federal and state authorities are reviewing our guideline, with a view to potentially integrating key components into the classification system of the forthcoming 6th edition of the German soil mapping guideline (KA6).
\end{abstract}

Keywords Anthrosols $\cdot$ Soil mapping guideline $\cdot$ Soil classification $\cdot$ Technogenic material $\cdot$ Technosols $\cdot$ Urban structure types

Responsible editor: Jianming Xue

Mohsen Makki

makki@hu-berlin.de

1 Department of Geography, Humboldt-Universität zu Berlin, 10099 Berlin, Germany
2 Berlin Senate Department for the Environment, Precautionary Soil Protection, Transport and Climate Protection, 10179 Berlin, Germany

3 Institut für Umwelt-Analyse Projekt-GmbH, 33729 Bielefeld, Germany 


\section{Introduction}

Soils play a decisive role in the ecosystem and fulfill natural and utilizing functions as specified in the German Soil Protection Act (BBodSchG 1998). They regulate climate, water, and matter balance; provide habitats and nutrients for plants and animals; and serve as an area for cultivating plants and food production. Simultaneously, they are an archive of natural and cultural history and serve as settlement areas (e.g., Morel et al. 2015). Since the industrial revolution in Europe in the nineteenth and twentieth centuries, more and more people have migrated to cities, which has progressively led to their spatial expansion and rapid land consumption for dwelling and industrial areas, commonly known as the urban sprawl (Couch et al. 2007). Urbanization is not an exclusively European process (Kojima 1996) but a development that affects soils in urban and peri-urban areas worldwide (Makki and Köhler 2013; Ceccarelli et al. 2014; Asabere et al. 2018; Wang et al. 2018). Due to this development, natural soil formation processes in urban environments can be severely disrupted. Based on the projections of the United Nations (United Nations, Department of Economic and Social Affairs, Population Division 2019), by the year 2050, more than $68 \%$ of the world's population will live in urban areas, leading to further disturbances of soil ecosystems. By shaping the surface, (re-)depositing natural and technogenic material, man is the dominant soil formation factor in urban and periurban areas, affecting natural soil formation factors, such as climate, relief, and parent rock, and thus altering soil properties.

\subsection{Soil properties in the urban environment}

Man-made alterations lead to heterogeneous and versatile soil types, properties, and distributional patterns in the urban environment. These attributes are often decoupled from natural soil formation factors and are highly reliant on the modifications. Soils in urban areas, for example, often contain an elevated humus content in the top and subsoil (Fig. 1). In the top and subsoils of the BMA, approximately 18.25 million tons of organic carbon are stored (Richter et al. 2020). The spatial distribution pattern, however, shows no naturally occurring pattern but is particularly dependent on land use (Fig. 2a and b). The large urban green spaces, such as Tiergarten, Tempelhof airfield, and Treptower Park in the city center, exhibit higher soil carbon stocks per hectare in the topsoil than the forested areas on the north-western and south-eastern outskirts (Fig. 2a). Soil carbon storage in the subsoil (Fig. 2b) varies even more and is dependent on the substrate available for soil formation. However, the measured organic carbon content is not exclusively attributable to soil organic matter of natural origin and genesis, but to a wide variety of technogenic organic substances or technogenic materials

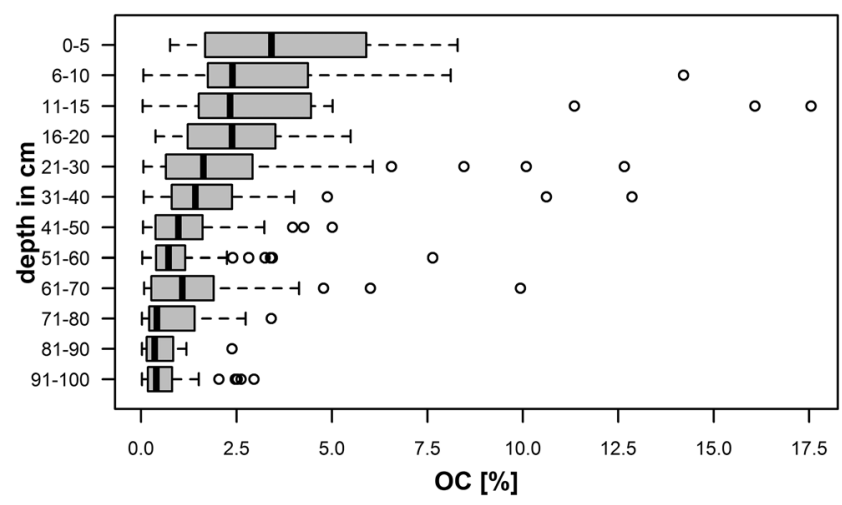

Fig. 1 Organic carbon contents $(N=441)$ of different soil types (natural and anthropogenic / technogenic) and urban structure types in the BMA, $(0-100 \mathrm{~cm})$, OC contents have been measured by loss-on-ignition method $\left(420^{\circ} \mathrm{C}\right)$, modified and extended acc. to Makki $(2015 \mathrm{~b})$

(Makowsky and Meuser 2007; Edmondson et al. 2012; Makki 2015b), especially in the urbanized districts of the BMA, which cannot perform the properties and functions of humus in the soil. There is still a lack of information in relation to how technogenic carbon can be reliably estimated during soil description. The humus content is just one example of how anthropogenic changes affect soil properties in the urban environment.

Furthermore, due to anthropogenic and technogenic material (concrete, rubble), soils in the BMA often exhibit a higher content of easily soluble lime from technogenic materials (Mekiffer 2008), which leaches into the subsoil over a period of years to several decades and can change the physical and chemical parameters of the soils (Blume and Runge 1978). Impervious or compacted soils can perform their ecosystem functions to a limited extent only (Wessolek 2008; Morel et al. 2015), and according to our observations, it is feasible that periodically reducing conditions are generated. From a pedogenetic and soil ecological perspective, these alterations generate modified and diversified properties of the parent material available for soil formation. Their inner structure and composition have influenced and will continue to influence other elements of the ecosystems, such as groundwater and biota (flora and fauna). Continuing urbanization and land consumption will further increase these processes. In the urban environment, for example, soil temperatures may be higher than in surrounding areas or in large urban green spaces (Senate Department for Urban Development and Housing 2020a); groundwater recharge may also be reduced due to the imperviousness of sealed surfaces (Wessolek 2001, 2008). Thus, soil surveys and the evaluation of soil-related information are a direct instrument in investigating the soil condition, to

Fig. 2 Organic carbon contents in (a) top- $(<20 \mathrm{~cm})$ and (b) subsoils $(20-100 \mathrm{~cm})$ of the Berlin metropolitan area in $\mathrm{t} \mathrm{ha}^{-1}$, Richter et al. (2020) 


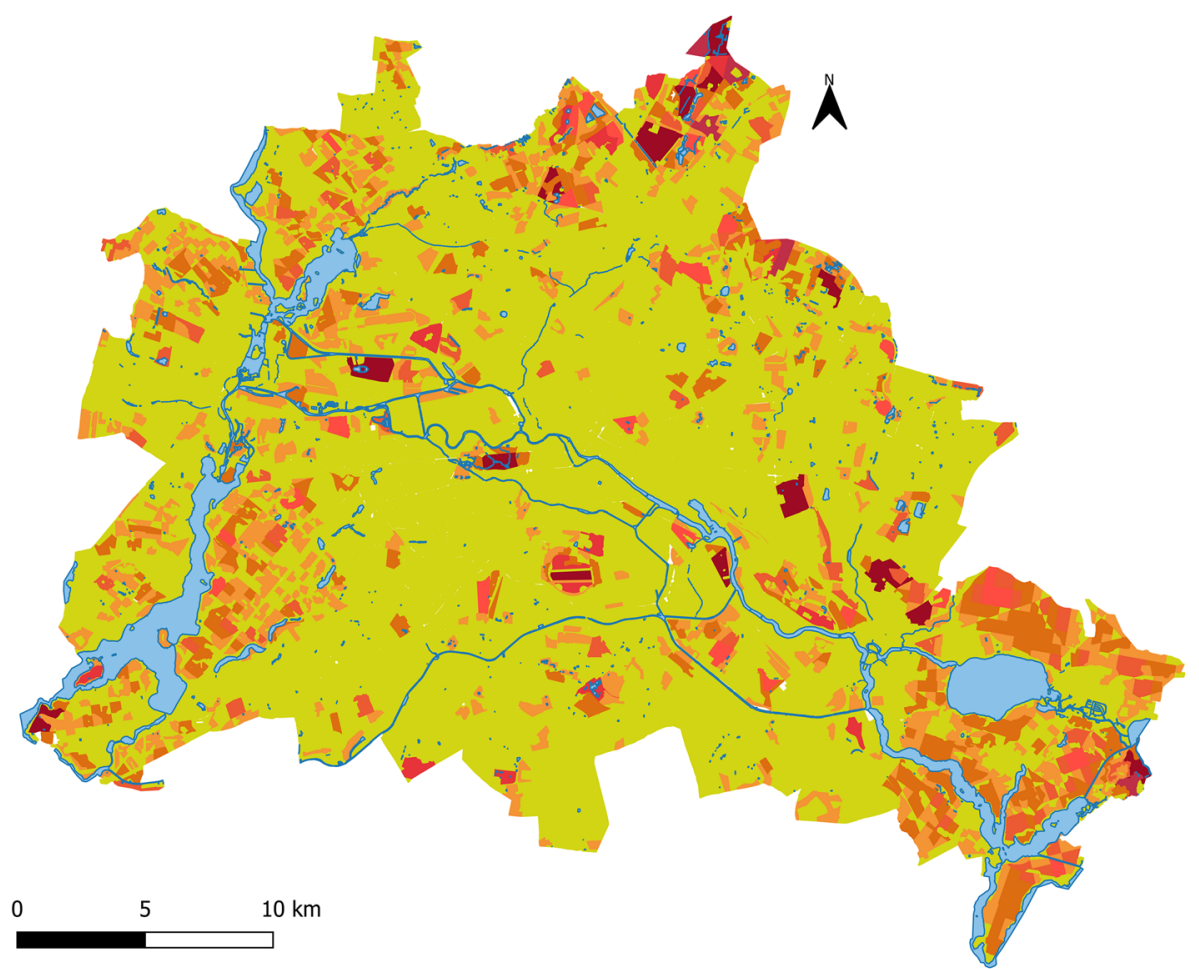

Legend

Waterbodies

Carbon storage in $\mathrm{t} / \mathrm{ha}$

$0-500$

$500-1000$

$1000-1500$

$1500-2000$

$2000-2500$

$2500-3000$

$3000-3500$

$>3500$

Author: Scarlet Richter

Coordinate System: DHDN /

Soldner Berlin

Basic Map: ISU 52015

Scale: 1:277502

Produced on: 27.06.2019

b

Carbon Storage in the Subsoil $(>20 \mathrm{~cm})$

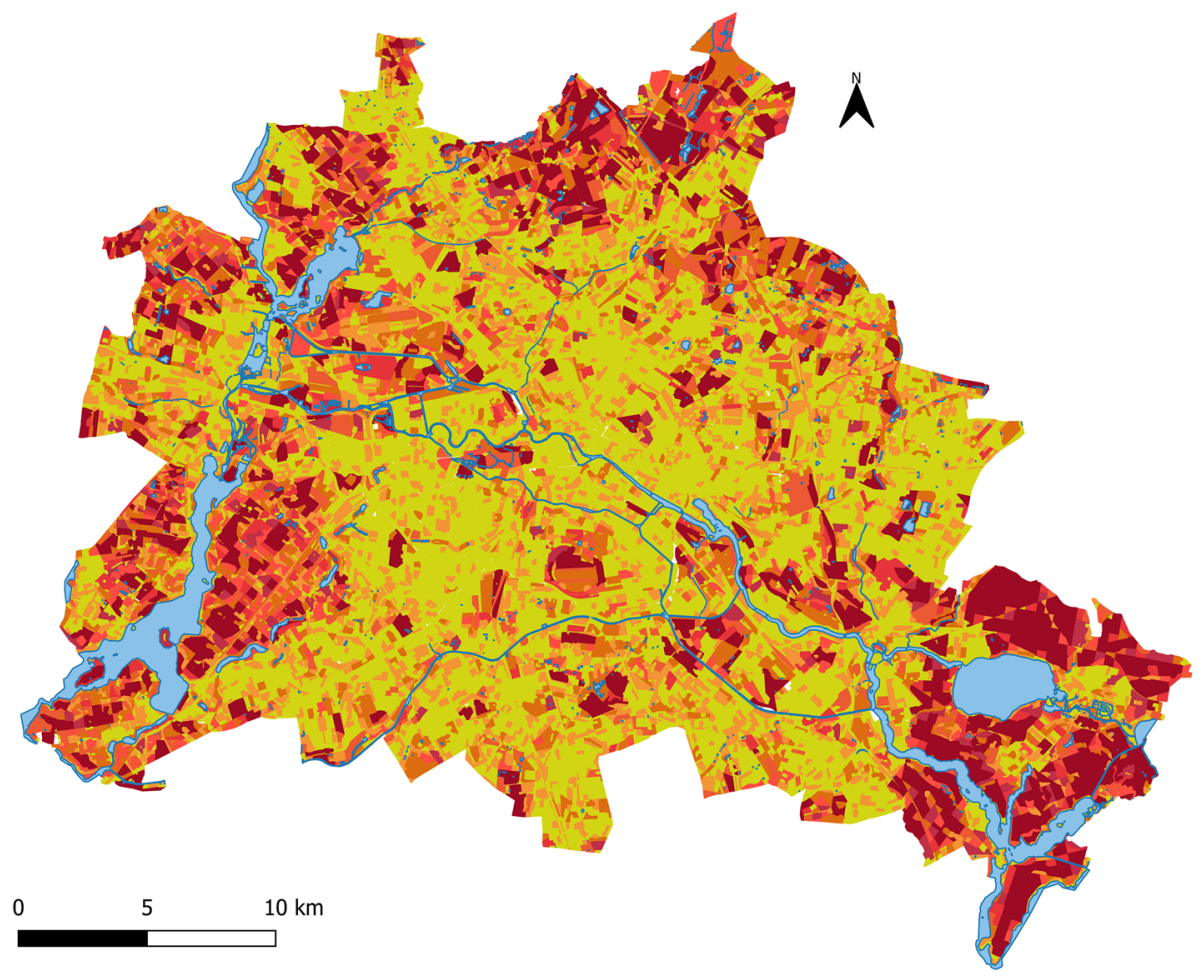

Legend

Waterbodies

Carbon storage in $\mathrm{t} / \mathrm{ha}$

0 - 500

$500-1000$

$1000-1500$

$1500-2000$

$2000-2500$

$2500-3000$

$3000-3500$

$>3500$

Author: Scarlet Richter Coordinate System: DHDN / Soldner Berlin

Basic Map: ISU 52015

Scale: 1:277502

Produced on: 27.06.2019 
understand and counteract human impact on soils, as well as designating and protecting soils of a particular value. These soil surveys require detailed soil description, new data fields, and the establishment of a point-related soil database in urban environments.

\subsection{Urban soil surveys and mapping in Germany}

Soil description and mapping are inherent measures in understanding soil formation processes in urban areas, in order to build sustainable cities for the twenty-first century. The implementation of the German Soil Protection Act (BBodSchG 1998) in 1998 established the nationwide legal basis for soil surveys, in relation to physical, chemical, and biological properties, as well as soil use. In Germany, the 5 th edition of the German soil mapping guideline (KA5, 'Bodenkundliche Kartieranleitung', 5th edition) is currently the national standard manual for describing and mapping soils (Ad-hoc AG Boden 2005), designed to investigate the majority of soil parameters by field methods. These soil surveys include creating detailed soil maps for federal and state authorities, as well as landscape designers and environmental planners. The term "soil mapping" is used synonymously for both soil description and the creation of soil maps. Due to the extraordinary heterogeneity of urban soil properties, however, soil description and mapping in urbanized areas are quite distinct from soil mapping in natural environments. For example, soil overview maps at national level are created to a scale of 1: 200, 000 and smaller (for further information, see: www.bgr.bund.de/ DE/Themen/Boden/Informationsgrundlagen/ Bodenkundliche_Karten_Datenbanken/BUEK200/buek200_ node.html)., These are based on soil surveys at a scale of 1: 50, 000. These existing approaches are not always applicable to the heterogeneous and multifaceted spaces of metropolitan areas like Berlin (Senate Department for the Environment, Transport and Climate Protection 2018a) with its dynamic history and continuous land use changes. On account of man-made modifications, spatio-temporal relationships for soil formation depending, inter alia, on age, geology, relief, and water conditions are interrupted or even cut off. Studies in urban areas show that, in contrast to rural areas, variations in the substrate or its properties (e.g., technogenic material, humus content or soil type) can occur in extremely small areas (Grenzius and Blume 1983; Grenzius 1993; Makki et al. 2014; Senate Department for the Environment, Transport and Climate Protection 2018a). Thus, completely different soil formation processes can take place within a few meters.

To create detailed soil maps in urban areas for users in the fields of urban/regional and landscape planning, ecologists, and other adjacent disciplines, a soil survey on a scale of at least 1:50,000 or 1:25,000 is necessary, as carried out in each federal state in Germany (BLA-GEO 2006). In urban areas such as the BMA, concepts for the derivation of soil overview maps at a scale of 1:25, 000, based on areal data (e.g., geology, land use, relief) and partial soil surveys, have already been developed (e.g., Grenzius and Blume 1983; Cordsen et al. 1988; Grenzius 1993). These medium-scale overview maps meet the requirements of the Berlin Land Use Plan (Senate Department for Urban Development and Housing 2020b) and the Landscape Programme (Senate Department for the Environment, Transport and Climate Protection 2017a) but are neither sufficient nor legally binding for planning tasks. Therefore, large-scale soil surveys and the creation of pointrelated data by urban soil mappers (1: 10, 000 or 1: 5000) are mandatory for the derivation of an accurate overview map (1: $50,000$ or $1: 25,000)$ for the implementation of planning tasks (e.g., preparation of a development plan, management of urban green spaces, reclamation of contaminated sites or nature conservation projects) and soil protection concerns. Only soil maps on a scale of 1:5000 meet the regulations of the legally binding land use plan ('Bebauungsplan') in terms of attention to detail. The identification of valuable areas for precautionary soil protection and for the conservation of protectable soils and soil functions, which goes hand in hand with describing and mapping the soil inventory, also contributes to the sustainable protection of soils (Gerstenberg 2015; Gerstenberg and Planungsgruppe Cassens+Siewert 2015; Senate Department for the Environment, Transport and Climate Protection 2018b). Currently, there are no stringent standardized criteria in the German soil classification system, specifying the description and mapping of urban soils and their properties at such a detailed level. Due to a lack of knowledge in relation to urban soil properties, the consistent application of soil survey specifications is often not assured. Besides broadening knowledge in relation to urban soils, providing detailed instructions is a key component in improving the quality of soil surveys and the derivation of soil maps. Therefore, existing methodologies must be further elaborated and enhanced for soil mappers in urban environments.

The initial national soil mapping guidelines, dating back to the 1950s, were not suitable and were designated to describe urban soil properties and types. In the BMA, urban soil surveys have a long and ongoing history that began in the early 1970s already (e.g., Sukopp et al. 1970; Blume et al. 1974; Burghardt et al. 2015; Makowsky et al. 2019). These works focused on the genesis of natural soils in urban environments, as well as the composition of technogenic soils (Runge 1975). A first definition of intentionally created soils in urban areas has been given by Bockheim (1974) who characterized urban soils as "a soil material having a non-agricultural, manmade surface layer more than $50 \mathrm{~cm}$ thick, that has been produced by mixing, filling, or by contamination of land surface in urban and suburban areas." This excludes anthropogenically altered soils which include agriculturally modified land (e.g., by plowing) (Fanning and Fanning 1989) or which assume that natural soils in the historical context became 
anthropogenic by human cultivation or clearing activities (Dudal 2004). In Germany, the term "soils of urban, commercial, industrial and montane reshaped area" was introduced (AK Stadtböden 1989). Subsequently, this term was replaced by the more appropriate concept of "soils of urban, industrial, traffic, mining and military areas" (SUITMAs) (Burghardt et al. 2015). Nevertheless, it should be pointed out that the term urban in this context could be rather misleading, as soils in urban forests or other remote areas may show no, or only minimal human impact. These soils have been named "natural urban soils" by Lehmann and Stahr (2007) or pseudo-natural soils by Morel et al. (2015).

Increasing research interest and efforts to extend soil classification systems to include urban soils of anthropogenic or technogenic origin have led to vital additions to the existing soil-systematic and substrate-systematic classifications worldwide. Prominent examples of the description of additional urban soil parameters and properties include the internationally valid World Reference Base for Soil Resources (WRB) by the IUSS Working Group WRB (IUSS Working Group WRB 2006, 2015; Schad 2018) and national soil classification systems of Germany (Ad-hoc AG Boden 1994, 2005; AK Stadtböden 1989, 1997a, b, 2001), Great Britain (Hollis 1991), Poland (Kabała et al. 2019), Russia (Stroganova and Prokofieva 2002), and the USA (Effland and Pouyat 1997; New York City Soil Survey Staff 2005). The integration of international soil classification into national soil classification systems and vice versa, however, is still difficult, since in specific urban areas, further standards and parameters, e.g., technogenic materials, such as war debris from World War II (Makki and Thestorf 2015) must be included in the soil mapping process, and soil description as well as mapping approaches differs greatly. These inconsistencies emphasize that for urban soil surveys, the description of the main features of urban soils needs to be harmonized in conjunction with regional features. An enhancement of the soil mapping methodology in urban areas is essential for planning processes, the determination of soil units, the derivation of resulting characteristic values (e.g., idealized "horizon-substrate-combinations" (Bauriegel 2005)), and the creation of soil maps. On the basis of soil description and mapping, and scientific investigations carried out in Berlin and other urban areas, the need arose to review existing standard works (AK Stadtböden 1989, 1997a, b, 2001; Ad-hoc AG Boden 1994, 2005; IUSS Working Group WRB 2006, 2015) relating to soil description and mapping and to implement essential additions aimed at describing urban soil properties not yet included in KA5 and other previous works.

\subsection{Objectives}

Soil surveys in urban areas differ greatly from mapping in rural areas. On behalf of the Berlin Senate Department for the
Environment, Transport and Climate Protection (SenUVK), and in close cooperation with the Working Group on Urban Soils of the German Soil Science Society (AGUB), (formerly 'AK Stadtböden'), a new methodological extension for describing and mapping soils in urban areas ('Anleitung für die bodenkundliche Kartierung im Land Berlin unter besonderer Berücksichtung anthropogener Böden im urbanen Bereich') has been developed. Based on the applied approach, a comprehensive guideline, following the standards of the German soil mapping guideline KA5 and AK Stadtböden, and taking into account more than 15 years of experience in the BMA, was conceptualized in order to standardize and improve the quality of soil surveys in the BMA. Our guideline serves as a generalizable soil description tool, which could be transferred to other urban areas. The main purpose of our guideline is to establish a legal framework for collecting uniform, point-related borehole and profile information, based on these instructions. In combination with the KA5 standard procedure, a point-related database for soils in the BMA is in the process of being set up by the Senate Department for the Environment, Transport and Climate Protection. Only by generating point-related soil data will the acquisition of soil information and the processing of collected point data for the creation of GIS-based maps covering larger areas be objectified and comprehensible. In so doing, neighboring disciplines (e.g., biology, archeology, climatology) will also benefit from the extended collection of parameters and the data that will be collected by the standards of this mapping guide. The implementation of a soil guideline specifically for urban soils in the BMA has the following objectives:

- Enhancement and extension of already existing data fields for the specific needs of urban areas

- Introduction of new complementary data fields for the requirements of urban soil description

- Revision, redesign, and supplementation of the list of anthropogenic relocated and technogenic materials, according to AGUB and KA5

- Development and extension of fact sheets (Supplementary Material) for soil profiles and technogenic material, as well as creation of revised recording sheets for urban soil description

Based on these objectives, our guideline is structured into 10 chapters, certain of which are further illustrated in this paper.

\section{Materials and methods}

\subsection{Literature review}

Our approach for extended description and mapping of soils in the BMA is based on the working experience of urban soil 


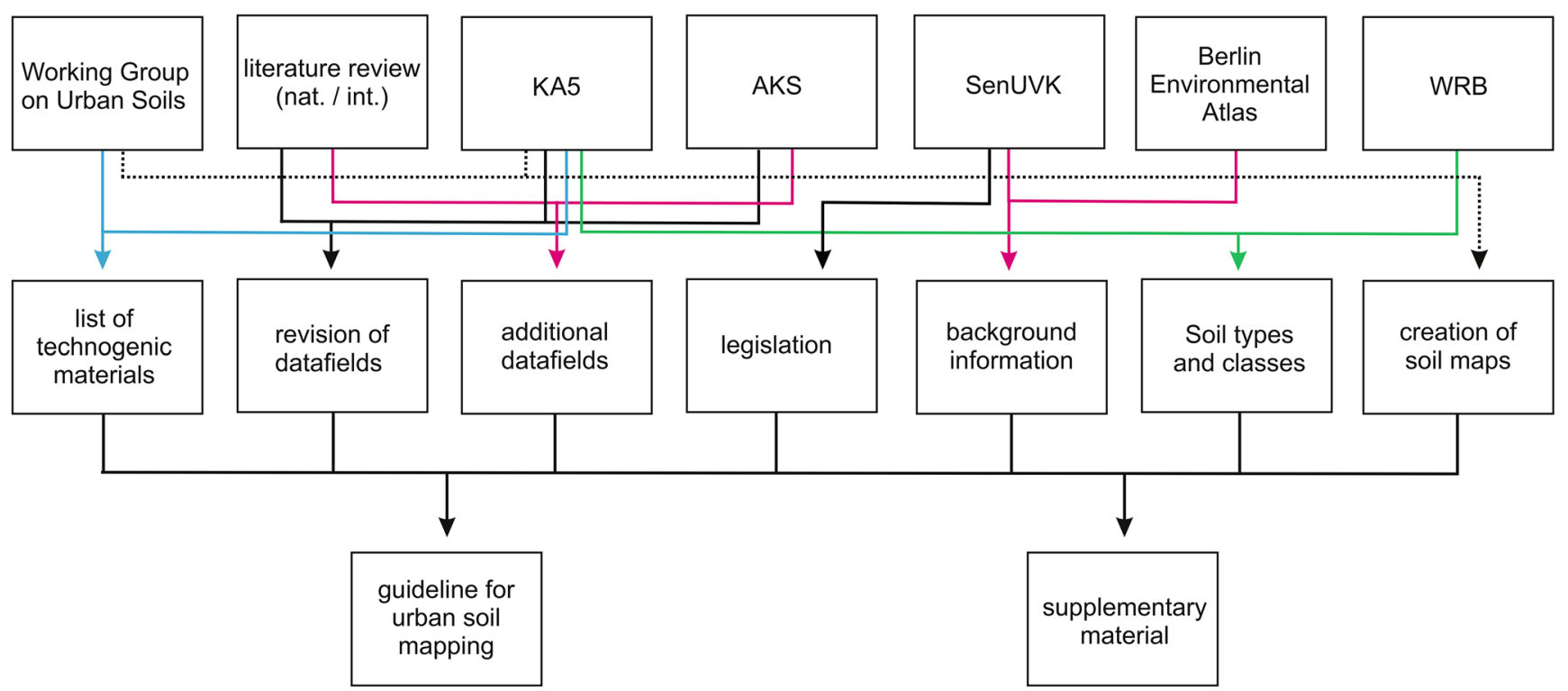

Fig. 3 Schematic structure of the data basis for the development of the mapping instructions, abbreviations: KA5, German Soil Mapping Guideline KA5; AKS, Working Group Urban Soils of the German Soil

Science Society; SenUVK, Berlin Senate Department for the Environment, Transport and Climate Protection; WRB, World Reference Base for Soil Resources

researchers over many years (Sukopp et al. 1970; Blume 1981; Grenzius 1987; Wessolek 2001; Makki et al. 2014) and local federal authorities who have performed detailed soil mapping projects in the BMA and have progressively revised the Berlin soil information system. Furthermore, a detailed review of national and international soil classification systems, primarily the 4th and 5th edition of the German soil classification systems (Ad-hoc AG Boden 1994, 2005), as well as working papers and guidelines for urban soil mapping (AK Stadtböden 1997a, b, 2001; Ad-hoc AG Boden 2009) has been carried out (Fig. 3). In our guideline, the main objectives of urban soil mapping in the BMA, the legal framework, as well as basic background information on natural and anthropogenic soil formation factors, are presented.

\subsection{Designation of soil categories, classes, and types in urban environments}

Currently, there is no consistency in the application of the terms urban soil or anthropogenic soil/technogenic soil in national and international soil classification systems. Against this background, the question arises as to how soils in urban areas should be defined and classified in the future. KA5 currently distinguishes between five soil types and 14 soil subtypes in the terrestrial anthropogenic soil class (Table 1), summarizing soil types with anthropogenic alterations. Additionally, soils with reductic properties which can be formed in urban areas by the release of reductive gases or the decomposition of organic substances in an anoxic environment are described as Reduktosole (soil class with four soil subtypes) (see also Blume and Felix-Henningsen 2014). This general pattern of anthropogenic soil types has not been changed. If a soil does not match one of the specified soil classes or types, the soil is treated as a young, naturally formed soil (A/C soil class), consisting of anthropogenic/technogenic material (Adhoc AG Boden 2005). Then, the parent material has to be further specified (in German soil classification: e.g., Regosol from building sand, Pararendzina from rubble (soil consisting of loose material with $\mathrm{CaCO}_{3} \geq 2-<75 \%$ )) for an unambiguous classification. Soils with a little anthropogenic cover or
Table 1 Classification of anthropogenic soil types in the "terrestrial anthropogenic soil" class (KA5) and their equivalent diagnostic horizons/materials in WRB (2015)

\begin{tabular}{|c|c|c|}
\hline Soil type & Diagnostic horizon in KA5 & $\begin{array}{l}\text { Diagnostic horizon/material in } \\
\text { WRB }\end{array}$ \\
\hline Kolluvisol & A horizon + Colluvic material $\geq 4 \mathrm{dm}$ & Colluvic material \\
\hline Plaggenesch & A horizon + Plaggic horizon $\geq 4 \mathrm{dm}$ & Plaggic or Terric horizon \\
\hline Hortisol & A horizon + Hortic horizon $\geq 4 \mathrm{dm}$ & Hortic horizon \\
\hline Rigosol & $\begin{array}{l}\text { Terric horizon, thickness } 4 \text { to } \geq 10 \mathrm{dm} \text {, starting at the } \\
\text { surface }\end{array}$ & Terric horizon thoroughly mixed \\
\hline Treposol & Terric horizon $>4 \mathrm{dm}$, starting at the surface & Terric horizon, single turnover \\
\hline
\end{tabular}

These soils do not represent urban soils containing relevant amounts of technogenic material 
mixing $(<30 \mathrm{~cm})$ are not considered as an independent soil type but as soil subtypes or varieties of soil types of natural genesis (Ad-hoc AG Boden 2005). In the WRB, urban soils of anthropogenic origin with $\geq 20 \%$ artifacts belong to the reference soil group Technosols (TC), which can be described in more detail by considering further information in relation to diagnostic horizons, properties, and materials. According to the WRB, artifacts include not only typical technogenic materials such as bricks or glass but also unweathered, relocated, or modified, natural parent material. Thus, Technosols can be classified sufficiently by 11 first-order qualifiers (principal qualifiers) and $39 \mathrm{~s}$ order qualifiers (supplementary qualifiers). On the other hand, cultivated organic-rich soils in allotments (in German soil classification: Hortisole), characterized by intensive composting and mixing ( $\geq 50 \mathrm{~cm}$ ), are classified as Anthrosols (e.g., Hortic Anthrosols, htAT) (IUSS Working Group WRB 2015; Schad 2018). In order to specify urban soils accurately, a revised definition for urban soils is given. To improve the designation of urban soil horizons and parent materials for $\mathrm{A} / \mathrm{C}$ soils, the list of technogenic materials has been extended (see section below), and the list of substrate thickness was modified (Table 2).

\subsection{Extension of existing data fields and implementation of new data fields}

The German soil classification system permits the acquisition of many soil parameters in the field, depending on the level of detail. In rural areas, KA5 is apt for soil description and mapping, but some urban soil properties cannot be described adequately.

Certain physical and chemical soil data, relevant for urban soil mapping, are not yet part of soil description with KA5. In order to ensure a uniform soil description in future soil surveys in the BMA, existing data fields (land use, parent material/ bedrock, etc.) of KA5 have been adjusted to the special conditions of the BMA soils. As some soil properties cannot be described with the already existing soil classification system, new additional data fields ( $\mathrm{pH}$ value, level of anthropogenic transformation) and keys have been developed. These data fields are of great relevance for the derivation of soil ecological maps and to estimate the human impact on soils in urban environments. Special emphasis was placed on the integration of our additional data fields into the already existing structure of the German soil classification system.

As discussions with other soil mapping experts from urban areas and our own mapping experience in the BMA have shown, soil description and mapping in urban environments are strongly reliant on expertise relating to the legal framework in cities, safety regulations, the many potential health risks, as well as the vast number of technogenic and anthropogenic materials. Therefore, we prepared the guideline in such a way that it is easily applicable and user-friendly. This includes integration into the KA5 working scheme, as well as the online accessibility and publication of geodata according to the specifications of the federal state of Berlin and the Directive 2007/2/EC of the European Parliament and of the Council (see also: https://eur-lex.europa.eu/legal-content/EN/ TXT/?uri=celex:32007L0002). Data fields and their need for application are thoroughly explained and illustrated by potentially occurring combinations. Supplementary material, such as fact sheets, (Appendices A-D) has been designed to support urban soil mappers in recognizing specific soil types, technogenic materials, and the classification of technogenic organic compounds.

\subsection{Extension of the list of anthropogenic and technogenic materials}

Investigations in the urban areas of Germany, namely Berlin (Makki 2013, 2015a), Essen (Meuser 1996a; Hiller and Meuser 1998), Halle (Sauerwein 2004), and Stuttgart (Holland 1996), revealed that only 33 to $50 \%$ of the layers, up to a depth of $100 \mathrm{~cm}$, are built up by natural parent rock material. These anthropogenic materials (and rocks) or technogenic substrates (Meuser 1996a, 2002, 2010) serve as the substrate for soil formation. They may be of anthropogenic and/or technogenic origin or anthropogenically relocated natural substrates (Ad-hoc AG Boden 2005). In urban soils, this material is usually a heterogeneous mixture of several different materials and/or components (Meuser et al. 1998) or anthropogenic and/or technogenic material mixed with natural
Table 2 Implementation of new lower limits for the substrate thickness for designating the substrate type sequence of nearsurface layers

\begin{tabular}{llll}
\hline Subdivision into depth levels (in dm) & Description & Signature (old) & Signature (new) \\
\hline $0-<1$ & Extremely shallow & $\ldots \backslash \ldots$ & $\ldots$ |cr $\ \ldots$ \\
$1-<2$ & Very shallow & & $\ldots /$ lcr $\ldots$ \\
$2-<3$ & Shallow & & $\ldots / \ldots$ \\
$3-<7$ & Moderately deep* & $\ldots / \ldots$ & $\ldots / \ldots$ \\
$7-<12$ & Deep & $\ldots / / \ldots$ & $\ldots / / \ldots$ \\
$\geq 12$ & Very deep & $\ldots / / / \ldots$ & $\ldots / / \ldots$ \\
\hline
\end{tabular}

* In KA5 soil classification, the term "over" is used instead of "moderately deep" 
soil, the composition of which changes within a horizon or layer by layer (Sauerwein 2004). Stratified technogenic materials may occur in constructed roadside soils, for example. Describing and above all the recognition of complex anthropogenic or technogenic materials is one of the great challenges for soil mappers in urban environments. The quantity and quality of data can vary greatly, depending on the wealth of experience. As soil surveys in the BMA showed a lack of knowledge and information in relation to these materials, our guideline will assist soil scientists in the description of anthropogenic and technogenic materials. The extension of the list of anthropogenic and technogenic materials is based on Hiller and Meuser (1998), the current draft of AGUB, and the description of technogenic materials by Meuser and Konen (2011).

\section{Results}

Fifty years of urban soil mapping in Germany and new challenges for sustainable urban planning rendered it necessary to develop a soil mapping guideline, especially for the needs of the urban environment. Since the development of previous works focusing on describing urban soils in Germany (AK Stadtböden 1997a, b, 2001), ongoing soil research in urban environments have provided new insights into soil properties and parent materials. These data cannot be collected by standard manuals for soil mapping. In our extended soil mapping guideline for the BMA, we focused on several aspects of urban soil science and soil description. The outcome of these practical and theoretical assumptions is a comprehensive guideline for describing natural and anthropogenic and/or technogenic soils and properties in the BMA, as an addition to the already existing soil mapping guideline for Germany (KA5) and the manuals by AK Stadtböden.

\subsection{Categories of urban soils}

One of the main recurring problems is the definition of the term "urban soils." Our categories for the classification of urban soils are based on the long history of urban soil surveys in the BMA and other international literature. For the purposes of simplification, we classify soils in urban areas into four genetic categories:

1. Soils from natural parent material and natural genesis

2. Soils from anthropogenically relocated natural parent material

3. Soils from anthropogenic and/or technogenic material and natural parent material (mixed or anthropogenic and/or technogenic overlaying natural material)

4. Soils exclusively from anthropogenic and/or technogenic material
All these categories show different degrees of human impact, at least in relation to the topsoil. In urban environments, anthropogenic and technogenic materials can cover the natural soils at shallow depths $(<30 \mathrm{~cm})$, and A/C soils may be anthropogenically assembled. In order to describe substrate changes at this level of detail, the list of substrate thickness is subdivided into two additional classes (Table 2).

\subsection{Extension and creation of additional soil-related data fields}

In the past, the Working Group on Urban Soils has already contributed additions to the national soil mapping guidelines (AK Stadtböden 1989, 1997a, b, 2001). Nevertheless, some data fields (e.g., land use types, lithogenic organic carbon content, parent rock material) of urban soil description still required revision and extensions in order to enhance the quality and validity of urban soil surveys. The necessity of a further subdivision of data fields for urban soil description will be explained and discussed (cf. Section 4.2) in the example of land use types and soil sealing, as well as in the extension of the list of anthropogenic and technogenic materials (cf. Section 4.4).

Since estimating the imperviousness of a surface does not form part of the standard soil description procedure, we recommend recording the degree of sealing. The overall degree of a sealed surface (in percentage) is estimated in the field and categorized into the impervious and/or partially impervious surface. Impervious and partially impervious surfaces are further subdivided into four different permeability classes (Senate Department for Urban Development and Housing 2017) (Table 3).

The German soil classification currently distinguishes between 35 anthropogenic and technogenic materials, which have been included since the 2005 edition (Ad-hoc AG Boden 2005). As technogenic materials are much more diverse, we extended the list to include 83 anthropogenic and technogenic materials and components, based on the AGUB draft and our own mapping experience in the BMA (Online Resource 1).

Data fields, such as $\mathrm{pH}$ and level of anthropogenic transformation (Table 4) that do not form part of the KA5 soil description procedure, have been elaborated to improve soil surveys in the urban environment. These data fields are especially important for the soil ecological assessment of urban soils (cf. Section 4.3).

\subsection{Supplementary material}

Supplementary material is provided in our guideline to assist soil mappers in describing soils in the BMA. Selected fact sheets of typical, near-, or semi-natural and anthropogenically formed soil types, horizons, and materials that are represented 
Table 3 Permeability classes for impervious, built-up impervious, and non-built-up impervious surfaces, modified after Senate Department for Development and Housing (2017)

\begin{tabular}{lll}
\hline $\begin{array}{l}\text { Permeability } \\
\text { class }\end{array}$ & $\begin{array}{l}\text { Effects on the } \\
\text { ecosystem }\end{array}$ & Pavement \\
\hline 1 & Extreme & $\begin{array}{l}\text { Asphalt, concrete, paving stones with joint sealing or concrete } \\
\text { substructure, synthetic surface materials }\end{array}$ \\
2 & High & $\begin{array}{c}\text { Artificial stones and slab coverings (edge length }>8 \mathrm{~cm} \text { ), concrete } \\
\text { composite paving, large paving }\end{array}$ \\
3 & Medium & $\begin{array}{l}\text { Small stone and mosaic paving (edge length }<8 \mathrm{~cm} \text { ) } \\
\text { Grass block pavers, unpaved surfaces (slags, gravel, loose rock), gravel } \\
\text { lawn }\end{array}$ \\
\hline
\end{tabular}

The lowest class number indicates the lowest permeability and the most serious imperviousness in the BMA (Appendix A of the guideline) have been created. These fact sheets have been configured to clearly describe typical soil types and materials, their distribution, as well as relevant processes occurring in the BMA. The description of soil types, horizons, and properties is designed according to the national KA5 standard. Appendix B gives further information relating to the physicochemical properties (e.g., color, odor, typical particle sizes, $\mathrm{pH}$ value), hazardous potential, and visual characteristics of technogenic materials. This compilation contains scientific findings in relation to technogenic compounds in urban soils over a 30-year period (e.g., Meuser 1996a, b; Hiller and Meuser 1998). Additional support is given by providing pictures of selected technogenic materials by Meuser and Konen (2011) and our own images. Furthermore, a "recording sheet for urban soil description" and a "drilling point protocol for urban spaces" (Appendix C of the guideline) have been developed. For urban soil description, these data sheets have been extended to meet the requirements of this soil guideline. They are essentially based on the German soil classification system but also contain new or supplemented data. Appendix D of the guideline describes and comprises analytical standard methods of organic key compounds of non-natural origin such as $\mathrm{PCB}, \mathrm{PAH}$, or BTEX.

Table 4 Level of anthropogenic transformation in the Berlin metropolitan area based on hemeroby classes of Blume (1990), Blume and Sukopp (1976), Gerstenberg (2015), Grenzius (1987), and Stasch et al. (1991)

\begin{tabular}{|c|c|c|c|c|}
\hline Code & $\begin{array}{l}\text { Level of } \\
\text { anthropogenic } \\
\text { transformation }\end{array}$ & Typical land use types & Diagnostic criteria & $\begin{array}{l}\text { "Closeness } \\
\text { to nature" }\end{array}$ \\
\hline n5 & $\begin{array}{l}\text { Not changed } \\
\text { Very little } \\
\text { alteration }\end{array}$ & Non-existent in the BMA & - & Very high \\
\hline n4 & Little alteration & Forest & Natural soils with (very) low human impact & High \\
\hline \multirow[t]{3}{*}{ n3 } & $\begin{array}{l}\text { Little to } \\
\text { moderate } \\
\text { alteration }\end{array}$ & Parks in the outer city, nature parks & Topsoil slightly modified & Moderate \\
\hline & \multirow[t]{2}{*}{$\begin{array}{l}\text { Moderate } \\
\text { alteration }\end{array}$} & $\begin{array}{l}\text { Grassland } \\
\text { Agricultural areas }\end{array}$ & Modified topsoil & \\
\hline & & $\begin{array}{l}\text { Parks and lawns, cemeteries, allotment gardens, weekend } \\
\text { homes, camping sites, arboretum residential areas (degree of } \\
\text { soil sealing <30\%) }\end{array}$ & $\begin{array}{l}\text { Modified top and partially modified subsoil, } \\
\text { may consist of anthropogenic/technogenic } \\
\text { material }\end{array}$ & \\
\hline \multirow[t]{2}{*}{$\mathrm{n} 2$} & Strong alteration & Former sewage farms & $\begin{array}{l}\text { strongly modified topsoil, subsoil moderately } \\
\text { altered }\end{array}$ & Little \\
\hline & $\begin{array}{r}\text { Very strong } \\
\text { alteration }\end{array}$ & $\begin{array}{l}\text { Parks and urban green spaces in the inner city area (mainly } \\
\text { consisting of anthropo-genic and/or technogenic material, } \\
\text { allotment gardens, urban brownfields, military area, open-pit } \\
\text { minings, railway areas, disposal sites }\end{array}$ & $\begin{array}{l}\text { Strongly modified soil (throughout the soil } \\
\text { profile), predominantly anthropogenic } \\
\text { and/or technogenic soils }\end{array}$ & \\
\hline \multirow[t]{3}{*}{ n1 } & \multirow[t]{3}{*}{$\begin{array}{l}\text { Extreme } \\
\quad \text { alteration }\end{array}$} & $\begin{array}{l}\text { sports grounds, settlement areas with moderate degree of soil } \\
\text { sealing }(30-60 \%)\end{array}$ & & Very little \\
\hline & & $\begin{array}{l}\text { City squares, railway tracks, settlement areas with high degree } \\
\text { of soil sealing }(60-90 \%)\end{array}$ & $\begin{array}{l}\text { Very strongly modified soil (throughout the } \\
\text { soil profile), predominantly anthropogenic } \\
\text { and/or technogenic soils }\end{array}$ & \\
\hline & & Settlement areas with extreme degree of soil sealing $(>90 \%)$ & $\begin{array}{l}\text { soils which have been completely reshaped by } \\
\text { deposition and removal, compaction, etc. }\end{array}$ & \\
\hline
\end{tabular}




\section{Discussion}

\subsection{General information on soil description in the BMA}

Some chapters of our guideline deal specifically with the exceptional characteristics of urban soil description in general, as well as in the BMA. Firstly, soil data are collected more frequently by manually drilled boreholes or shallow pits than in profiles, and due to complex ownership issues, suitable sites for soil surveys are often limited. Our approach presents certain methods, e.g., how locations should be chosen in order to create valid data for the investigated site and how maps could be derived, even if soil information is incomplete. Secondly, numerous pipes and channels for the supply of electricity, gas, and drinking and process water, as well as the disposal of wastewater and telecommunications, are laid underground. In addition, ammunition remnants and duds from World War II, which have not yet been removed or detected, are repeatedly found in the BMA. Therefore, our soil guideline provides useful recommendations and instructions with regard to dealing with issues, such as ammunition and other obstacles in the soil (Senate Department for the Environment, Transport and Climate Protection 2017b). As the legal framework for soil mapping may vary from state to state, these chapters also include local laws, such as the Berlin Soil Protection Law (BlnBodSchG 2004) and the National Nature Protection Law (BNatSchG 2009). Soil surveyors must prove their knowledge before they are permitted to begin their investigations. Finally, soil mappers require certain accurate information in relation to the study area. Our soil guideline provides useful background information relating to local soil formation factors in the BMA, such as geological and climatic conditions, and links to available and easily accessible environmental data. The Berlin Environmental Atlas (for further information see: https://www. stadtentwicklung.berlin.de/umwelt/umweltatlas/edua_index. shtml) and the geodatabase of the state of Berlin (for further information see: https://fbinter.stadt-berlin.de/fb/index.jsp? Szenario $=\mathrm{fb}$ _en) offer comprehensive datasets and detailed information with regard to the soil environment in the BMA at the block level. These services are allocated free of charge and facilitate the soil survey procedure by providing estimates in relation to soil condition and soil type. The future point-related soil database for the BMA will be integrated in these services and, by providing point-related data, will improve the quality of the derived maps. Only by creating such a database will legally binding soil information be supplied.

\subsection{Extension of existing soil-related data fields}

Berlin's cityscape has undergone significant changes, especially since industrialization and its aggregation to the greater Berlin area in 1920. Former arable land on the Barnim and Teltow uplands was converted to residential and industrial areas.
Industrial plants were initially built along the Spree River and other transportation routes and have migrated with steady urban development toward the outskirts of the city. Currently, unused former industrial facilities are converted for residential purposes. World War II and the destruction of many residential and industrial buildings and infrastructure also had a tremendous impact on the urban landscape. Thus, anthropogenic and technogenic materials of earlier land use can be found in many areas of Berlin. Other technogenic materials can be found along road sites and railway lines, where the soils have been created by depositing different anthropogenic materials.

Land use is a crucial factor for soil properties in the BMA and urban areas in general. Both the former and the more recent land use of the investigated area have a decisive influence on soil formation factors and processes, as well as on physical (e.g., compaction, texture, and coarse soil content) and chemical soil properties (e.g., heavy metal contents, lime, and humus content) (e.g., Pouyat et al. 2007; Greinert 2015). Information on land use and land change can, inter alia, provide useful background information, indicating whether the area under investigation exhibits soil pollution or other potential hazards. The reconstruction of the land use history and, consequently, the origin of various anthropogenic and technogenic materials is crucial for urban soil description (Schneider and Makowsky 2017). Hitherto, urban land use types have been underrepresented in soil description that have been mostly related to agricultural activities, grazing, or forest management (Ad-hoc AG Boden 2005; Food and Agricultural Organization 2006). As far as this information can be reconstructed, for instance, by means of historical records or cadastral data, up to five land use types should be chronologically indexed. For this purpose, a stronger subdivision was created, based on urban structure types (Sauerwein 2004; Senate Department for Urban Development and Housing 2016a) and the Berlin Land Use Plan (Senate Department for Urban Development and Housing 2020b).

Land use and different urban structure types are closely related to soil sealing. Soil sealing or the imperviousness of soils is defined as compaction or covering of the natural soil layers by (technic hard) materials of different permeability (e.g., concrete or asphalt) but also buildings (Table 3). On account of these interventions, the natural, abiotic, and biotic interactions between the pedosphere and atmosphere, such as infiltration, evaporation, groundwater recharge rates, and gas exchange, are disturbed (Wessolek 2001). The higher the degree of soil sealing, the higher is the impact on ecosystem services, such as biological activities, living space for soil organisms, and the water regime. At present, $33.9 \%$ of all areas in Berlin are considered to be impervious, including water bodies and roads. Excluding water bodies, but including streets, the proportion of sealed areas is $36.1 \%$. In the Berlin Environmental Atlas by the Senate Department for Urban Development and Housing (2017), impervious soil coverage or soil sealing is divided into two categories: (a) built-up impervious (e.g., buildings) and (b) non-built-up 
impervious (e.g., parking lots, streets). Although Berlin has evolved as a multicenter metropolis, the degree of sealing in the BMA tends to reflect the urban-rural gradient (McDonnell and Pickett 1990), which assumes the highest degree of human impact in the inner-city districts. Over the last decade, we have observed a tremendous effect of sealing on urban soils and their associated ecosystems. As an example, a total soil sealing at local level (e.g., next to roads) diminishes the infiltration rate and evaporation in such a way that plant growth, especially that of young, freshly planted trees, is inhibited to a great extent. This causes severe stress for street trees, and according to investigations of the Berlin Senate Department for Urban Development and Housing, around $42 \%$ of all trees are impaired. Another 5\% are severely damaged or already dead (Senate Department for Urban Development and Housing 2016b). On the other hand, large urban green spaces, such as the former Tempelhof airfield or Tiergarten area and forests, cool down the surface and the air temperature. These areas play a significant role in the urban climate, by decreasing the effect of the urban heat island (Senate Department for Urban Development and Housing 2020a). It is also relevant to note that materials which reduce the imperviousness locally, such as lawn paving stones, can improve the infiltration rate at the microscale (Wessolek 2001). Estimates of the imperviousness of soils per area and land use type are available in the Environmental Atlas of Berlin (Senate Department for Urban Development and Housing 2017). In order to carry out a detailed and site-specific, soil ecological assessment, the overall degree and type of sealing (Table 3) of the investigated area should be considered.

\subsection{Creation of additional soil-related data fields}

Soil $\mathrm{pH}$ is an important criterion for the assessment of soil ecological features. The degree of acidification or alkalinity impacts the chemical, physical, and biological processes of the soil
(Bolan and Kandaswamy 2005). pH promotes or inhibits the formation of a stable soil structure (Bronick and Lal 2005); thus, it is a factor controlling the water and air balance, root penetration, and living conditions of soil organisms. A favorable $\mathrm{pH}$ environment ensures the availability of nutrients and controls the adsorption and desorption of heavy metals. It further regulates soil reactions, as well as soil formation processes (Blum 2012). While the $\mathrm{pH}$ in natural sites in the BMA usually follows a natural distribution pattern, anthropogenically influenced soils often exhibit a large range (Fig. 4), with a tendency to increase from top to subsoil or underground (Makki 2015b). $\mathrm{pH}$ values in Podzols ( $\mathrm{pH} \sim 3-4.5)$ and Cambisols $(\mathrm{pH} \sim 4-5)$ are generally low, while Luvisols ( $\mathrm{pH} \sim 5-7.5$ ) are moderately acidic to very slightly alkaline. In urban areas, extremely variable $\mathrm{pH}$ values can also occur in soils of natural origin. A high $\mathrm{pH}$ value is attributable to technogenic calcareous material (Mekiffer 2008) as well as to the application of de-icing salts along roadsides and diffuse calcareous dust inputs (Chinnow 1975). Soils from anthropogenic and/or technogenic lime-bearing parent materials (e.g., a Pararendzina consisting of rubble, debris, or concrete) show $\mathrm{pH}$ values between 6 and 8 . In order to consider soil $\mathrm{pH}$ in urban soil description, the new data field soil $p H$ has been developed. Soil $\mathrm{pH}$ shall be measured in the field or the laboratory by standard procedures, whereas the method selected has to be included in the description. The $\mathrm{pH}$ values are classified according to KA5 (Ad-hoc AG Boden 2005).

\subsection{Extension of the list of anthropogenic and technogenic materials}

Anthropogenic and technogenic materials are extensively distributed across the BMA (Makki 2015b). They occur either as heterogeneous/homogenous parent material or as single components (Online Resource 1). The description and recognition of these substrates are essential, as this material provides the
Fig. $4 \mathrm{pH}$ values in BMA $(N=$ 1.794) grouped by urban structure type, soil samples were taken at depths between 0 and $100 \mathrm{~cm}$, modified and extended acc. to Makki (2015b), compiled by K. Thestorf

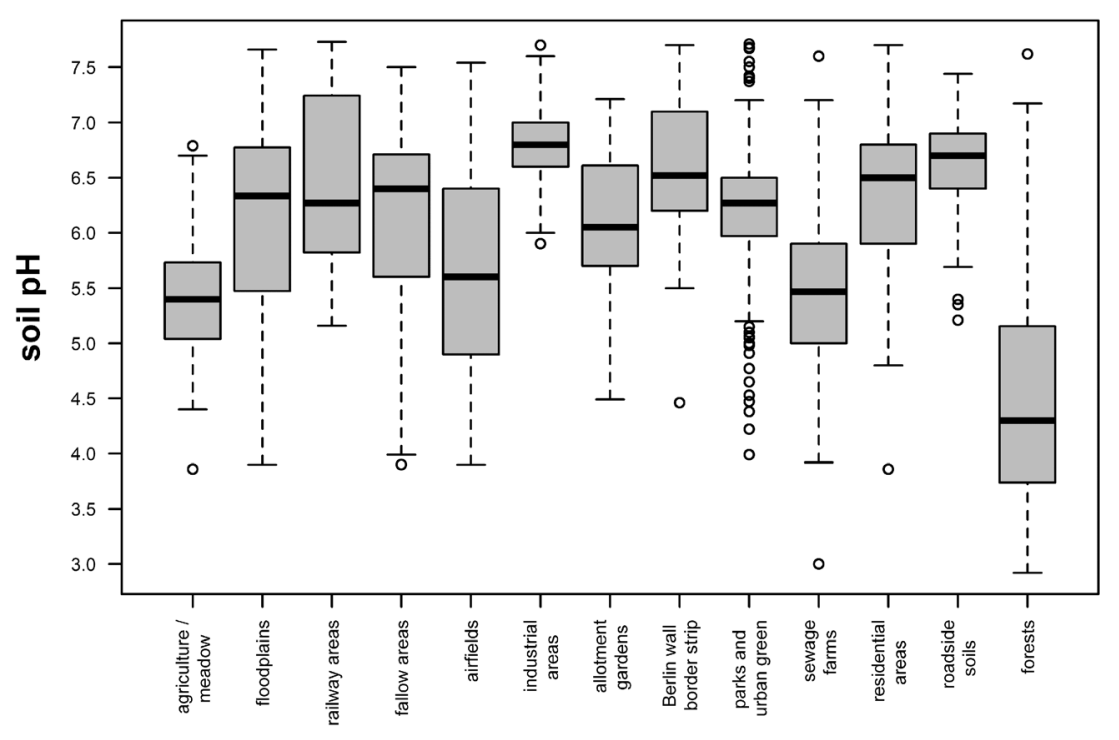


parent material for soil formation. The physical and chemical properties of technogenic materials can potentially harm the environment and will affect recent and future soil formation processes and properties. For precautionary soil protection and remediation purposes, as well as urban soil surveys in general, it is necessary to describe anthropogenic and technogenic materials as accurately as possible. Our extended list includes anthropogenic and technogenic materials (e.g., subdivision of steelwork slags and sludges) which are frequently found in urban areas such as war debris (e.g., around 75 million $\mathrm{m}^{3}$ from World War II in Berlin, Makki and Thestorf 2015) and ashes and slags (Fig. 5a and b) which potentially occur in the BMA but are also abundant in other cities in Germany (Meuser 1996a; Hiller and Meuser 1998; Schneider and Makowsky 2017). By adding further anthropogenic and technogenic materials for soil formation, we will ensure that anthropogenic and technogenic compounds will be identified more accurately. We also believe that the specification of certain technogenic materials in the WRB could require some revision, as many anthropogenic and technogenic materials with quite different physical and chemical properties (e.g., ashes, rubble, slags) are summarized by the Technic and Spolic qualifier (Online Resource 1 and Table 5). This would help improve the quality of describing and mapping urban soils with the WRB, facilitating and simplifying the comparison of different Anthrosols and Technosols.

\section{Conclusions}

Over the last few decades, numerous soil surveys have been carried out in the BMA, which provide a great deal of information about soil conditions in the state of Berlin. These results
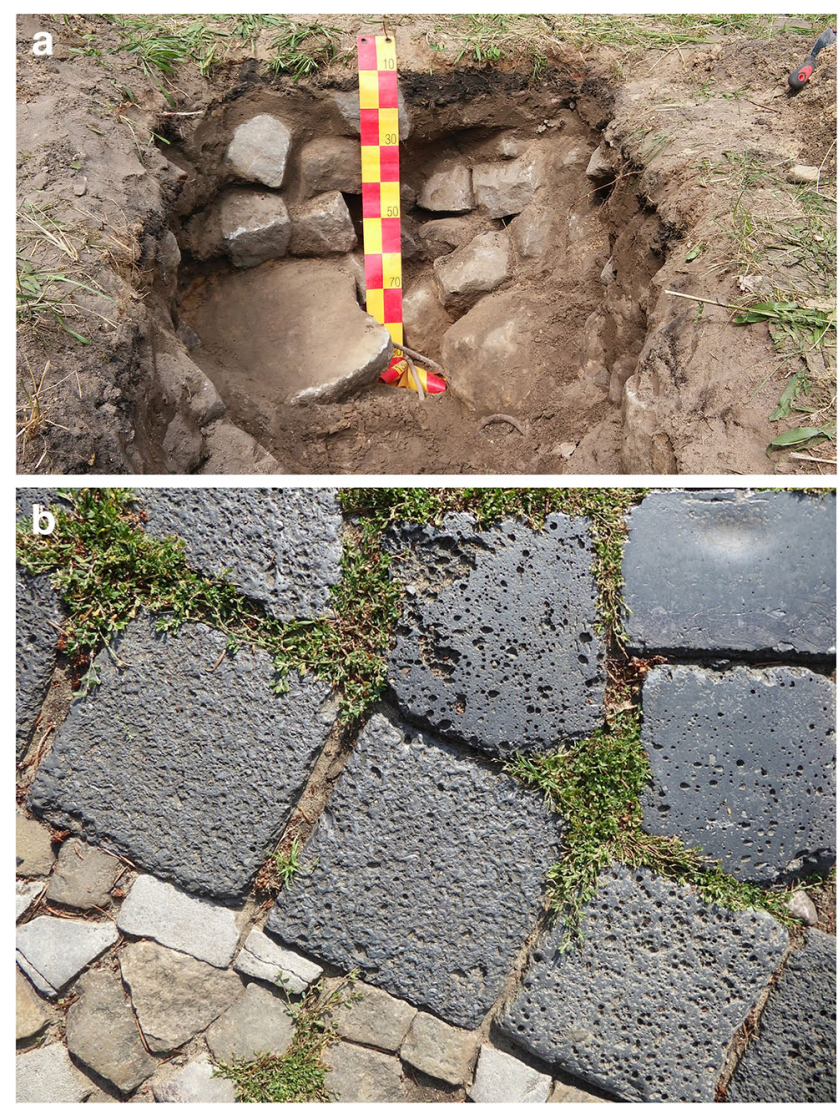

Fig. 5 (a) Soil profile on a former shooting range site consisting of different technogenic and anthropogenic materials, $0-10 \mathrm{~cm}$, anthropogenic A horizon (natural soil material); $10-18 \mathrm{~cm}$, technogenic $\mathrm{C}$ horizon (bitumen or tar); $18-60 \mathrm{~cm}$, technogenic $\mathrm{C}$ horizon (construction sand + granitic pavement stones); $>60 \mathrm{~cm}$ technogenic $\mathrm{C}$ horizon (calcareous construction sand + ferro concrete). (b) Copper slag as paving stones, photos by $\mathrm{K}$. Thestorf
Table 5 Comparison of the list of anthropogenic and technogenic materials in this guideline with the German soil classification KA5 (Ad-hoc AG Boden 2005) and their respective qualifier or horizon in the IUSS Working Group WRB (2015)

\begin{tabular}{lll}
\hline $\begin{array}{l}\text { German soil classification } \\
\text { (KA5) }\end{array}$ & Anthropogenic/technogenic material (this guideline) & $\begin{array}{l}\text { Qualifier/horizon in the } \\
\text { WRB }\end{array}$ \\
\hline Building rubble & $\begin{array}{l}\text { Rubble from residential and commercial } \\
\text { buildings/roads /World War II } \\
\text { Cement (component) }\end{array}$ & Urbic \\
& $\begin{array}{l}\text { Bricks (component) } \\
\text { Ashes }\end{array}$ & Technic \\
Ashes & Slags & Spolic \\
Slags & Dumped material & Spolic \\
Dumped material & Anthroorganics & Spolic \\
Anthroorganics & Anthropogenic hard rock & Hortic/Terric \\
Anthropogenic hard rock & Anthropogenic loose rock & Ekranic/Technic \\
- & Natural soil/relocated material & Technic \\
Natural soil/relocated ma- & (Hortic)/anthric/Terric \\
terial & Domestic wastes & Garbic \\
Wastes & Industrial wastes & Technic \\
Sludges & Sludges & Spolic
\end{tabular}


proved the complexity and diversity of urban soils, highlighting the necessity of crucial extensions and the demand for standardization of future soil mapping campaigns in urban environments. Our guideline will enable the future, large-scale mapping of point-related soil data in the state of Berlin, with respect to specific urban soil parameters. By adapting and extending the data fields to include urban soil conditions, our methodological approach provides an instrument, capable of capturing the special soil parameters of urban soils in the state of Berlin efficiently. The instructions for soil surveys, presented in our soil guideline, are a far-reaching supplement to the national standard, KA5. According to our knowledge, our guideline is the first comprehensive manual for the description of urban soils in Europe, within a national soil classification system. This mapping guideline will be the future standard work for describing soils in the federal state of Berlin. For the depiction of anthropogenic and technogenic soils in soil maps, the standards of the Federal Institute for Geosciences and Natural Resources (graduated violet colors and legend numbers) must be used (Ad-hoc AG Boden 2005). In the Berlin Environmental Atlas, derived soil maps, based on these specifications and urban land use types, as well as on certain soil properties, have already been created (Senate Department for the Environment, Transport and Climate Protection 2018a, c).

We are currently in discussion with representatives from federal and state authorities with regard to integrating key components of our guideline into the classification system of the next edition of the German soil mapping guideline, KA6. This highlights the possibility of transferring the BMA outcomes to the national level.

Supplementary Information The online version contains supplementary material available at https://doi.org/10.1007/s11368-020-02832-8.

Acknowledgments The authors wish to thank Dr. Dieter Kühn and Dr. Albrecht Bauriegel (Brandenburg State Office for Mining, Geology and Raw Materials) for the provision of many useful information and their participation in fruitful discussions.

Funding Open Access funding enabled and organized by Projekt DEAL. The development of the soil guideline for mapping anthropogenic soils by MM and KT was funded by the Senate Department for the Environment, Transport and Climate Protection.

Open Access This article is licensed under a Creative Commons Attribution 4.0 International License, which permits use, sharing, adaptation, distribution and reproduction in any medium or format, as long as you give appropriate credit to the original author(s) and the source, provide a link to the Creative Commons licence, and indicate if changes were made. The images or other third party material in this article are included in the article's Creative Commons licence, unless indicated otherwise in a credit line to the material. If material is not included in the article's Creative Commons licence and your intended use is not permitted by statutory regulation or exceeds the permitted use, you will need to obtain permission directly from the copyright holder. To view a copy of this licence, visit http://creativecommons.org/licenses/by/4.0/.

\section{References}

Ad-hoc AG Boden (1994) Bodenkundliche Kartieranleitung, 4th edition. Schweizerbart, Hannover

Ad-hoc AG Boden (2005) Bodenkundliche Kartieranleitung, 5th edition. Schweizerbart, Hannover

Ad-hoc AG Boden (2009) Arbeitshilfe für die Bodenansprache im vorund nachsorgenden Bodenschutz - Auszug aus der Bodenkundlichen Kartieranleitung KA5. Schweizerbart, Hannover

AK Stadtböden (1989) Empfehlungen des Arbeitskreises „Stadtböden“ der Deutschen Bodenkundlichen Gesellschaft für die bodenkundliche Kartierung urban, gewerblich, industriell und montan überformter Flächen (Stadtböden). UBA Texte 18/89, Berlin

AK Stadtböden (1997a) Empfehlungen des Arbeitskreises Stadtböden der Deutschen Bodenkundlichen Gesellschaft für die bodenkundliche Kartierung urban, gewerblich, industriell und montan überformter Flächen (Stadtböden), Teil 1: Feldführer, 2. Auflage, Kiel

AK Stadtböden (1997b) Empfehlungen des Arbeitskreises Stadtböden der Deutschen Bodenkundlichen Gesellschaft für die bodenkundliche Kartierung urban, gewerblich, industriell und montan überformter Flächen (Stadtböden), Teil 2: Handbuch, 2. Auflage, Kiel

AK Stadtböden (2001) Stadtbodenkartierung, Ergänzung der KA4 um stadtbodenspezifische Besonderheiten https://www.bgr.bund.de/ DE/Themen/Boden/Netzwerke/AGBoden/Downloads/Archiv/ AGBoden_Archiv.html. Accessed 12 Dec 2019

Asabere SB, Zeppenfeld T, Nketia KA, Sauer D (2018) Urbanization leads to increases in $\mathrm{pH}$, carbonate, and soil organic matter stocks of arable soils of Kumasi, Ghana (West Africa). Front Environ Sci 6: 119. https://doi.org/10.3389/fenvs.2018.00119

Bauriegel A (2005) Methoden zur Ableitung und Parametrisierung von flächenbezogenen Profil- und Horizontdaten. Dissertation, Humboldt-Universität zu Berlin. https://doi.org/10.18452/15211

BBodSchG (1998) Bundes-Bodenschutzgesetz vom 17. März 1998 (BGB1. I S. 502), das zuletzt durch Artikel 3 Absatz 3 der Verordnung vom 27. September 2017 (BGB1. I S. 3465) geändert worden ist, www.gesetze-im-internet.de/bbodschg/. Accessed 30 Dec 2019

BLA-GEO (2006) Konzept für eine Vereinheitlichung der Bodenkarte 1: 50.000 (BK50), Bericht im Auftrag des BLA-GEO vom 27./ 28.09.2006, Königswinter. https://www.bgr.bund.de/DE/Themen/ Boden/Netzwerke/AGBoden/Downloads/Konzept_BK50.html. Accessed 12 Dec 2019

BlnBodSchG (2004) Berliner Gesetz zur Ausführung des BundesBodenschuzgesetzes vom 24. Juni 2004 https://www.berlin.de/ senuvk/umwelt/bodenschutz/de/fragen/download/blnbodschg.pdf Accessed 30 Dec 2019

Blum WEH (2012) Bodenkunde in Stichworten, 7th edition. Borntraeger, Berlin-Stuttgart

Blume HP (ed) (1981) Typische Böden Berlins. Exkursionsführer zur Jahrestagung der DBG und eines Internationalen Symposiums über bodenkundliche Probleme städtischer Verdichtungsräume in Berlin (West). Mitt Dtsch Bodenkdl Ges 31

Blume HP (ed) (1990) Handbuch des Bodenschutzes - Bodenökologie und -belastung, Vorbeugende und abwehrende Schutzmaßnahmen, ecomed, Landsberg

Blume HP, Felix-Henningsen P (2014) Reduktosole. In: Blume HP, Felix-Henningsen P, Fischer WR, Frede HG, Horn R, Stahr K (eds) Handbuch der Bodenkunde. https://doi.org/10.1002/ 9783527678495.hbbk2008001

Blume HP, Runge M (1978) Genese und Ökologie innerstädtischer Böden aus Bauschutt. Z Pflanzenernähr Bodenkd 141(6):727-740. https://doi.org/10.1002/jpln.19781410610 
Blume HP, Sukopp H (1976) Ökologische Bedeutung anthropogener Bodenveränderungen. In: Bundesanstalt für Vegetationskunde, Naturschutz und Landschaftspflege (ed) Veränderungen der Flora und Fauna in der Bundesrepublik Deutschland, Schriftenreihe für Vegetationskunde 10, pp. 75-89

Blume HP, Böcker R, Drewes H, Dümmler H, Haberland, W et al. (1974) Ökologisches Gutachten Berlin (west) - Gatow/Kladow, Ruhwald/ Spreetal. Technical report, $282 \mathrm{pp}$

BNatSchG (2009) Bundesnaturschutzgesetz vom 29. Juli 2009 (BGB1 I S 2542), das zuletzt durch Artikel 8 des Gesetzes vom 13 Mai 2019 (BGB1 I S 706) geändert worden ist https://www.gesetze-iminternet.de/bnatschg_2009/ Accessed 30 Dec 2019

Bockheim JG (1974): Nature and properties of highly disturbed urban soils, Philadelphia, Pennsylvania. Paper presented before div. S-5, soil genesis, morphology and classification, annual meeting of the soil science Society of America, Chicago, Illinois

Bolan NS, Kandaswamy K (2005) pH. In: Hillel D (ed) Encyclopedia of soils in the environment. Academic Press, London, pp 196-202

Bronick CJ, Lal R (2005) Soil structure and management: a review. Geoderma 124:3-22. https://doi.org/10.1016/j.geoderma.2004.03. 005

Burghardt W, Morel JL, Zhang GL (2015) Development of the soil research about urban, industrial, traffic, mining and military areas (SUITMA). Soil Sci Plant Nutr 61/sup1:3-21. https://doi.org/10. 1080/00380768.2015.1046136

Ceccarelli T, Bajocco S, Luigi Perini L, Luca Salvati L (2014) Urbanisation and land take of high quality agricultural soils - exploring long-term land use changes and land capability in northern Italy. Int J Environ Res 8(1):181-192

Chinnow D (1975) Bodenveränderungen durch carbonate und Streusalze im west-Berliner Stadtgebiet. Mitt Dtsch Bodenkdl Ges Ges 22: 355-358 https://www.dbges.de/de/system/files/mitteilungen dbg/ Mitteilungen-der-DBG-1975_22.pdf. Accessed 11 Aug 2020

Cordsen E, Siem HK, Blume HP, Finnern H (1988) Bodenkarte 1:20000 Stadt Kiel und Umland. Mitt Dtsch Bodenkdl Ges 56:333-338 https://www.dbges.de/de/system/files/mitteilungen_dbg/ Mitteilungen-der-DBG-1988_56.pdf. Accessed 23 Aug 2020

Couch C, Leontidou L, Petschel-Held G (eds) (2007) Urban sprawl in Europe - landscapes, Land-use Change \& Policy. Blackwell, Oxford

Dudal R (2004) The sixth factor of soil formation, Presented at the "International Conference on Soil Classification 2004", 3-5. August 2004, Petrozavodsk, Russia

Edmondson JL, Davies ZG, McHugh N, Gaston KJ, Leake JR (2012) Organic carbon hidden in urban ecosystems. Sci Rep 2:963. https:// doi.org/10.1038/srep00963

Effland WR, Pouyat RV (1997) The genesis, classification, and mapping of soils in urban areas. Urban Ecosyst 1:217-228. https://doi.org/10. 1023/A:1018535813797

Fanning DS, Fanning MCB (1989) Soil: morphology, genesis, and classification. Wiley, New York

Food and Agricultural Organization (2006) Guidelines for soil description, 4th edition. Food and Agricultural Organization of the United Nations, Rome

Gerstenberg JH (2015) Erstellung von Karten zur Bewertung der Bodenfunktionen, Senatsverwaltung für Stadtentwicklung und Umwelt (ed) Berlin, https://www.stadtentwicklung.berlin.de/ umwelt/umweltatlas/eld1 12.htm. Accessed 12 Dec 2019

Gerstenberg JH, Planungsgruppe Cassens+Siewert (2015) Planungshinweise zum Bodenschutz Leitbild und Maßnahmenkatalog für den vorsorgenden Bodenschutz in Berlin, im Auftrag der Senatsverwaltung für Stadtentwicklung und Umwelt, Berlin, http://www.stadtentwicklung.berlin.de/umwelt/ umweltatlas/download/gerstenberg2015_Leitbild_Ma\%C3\% 9Fnahmenkatalog.pdf. Accessed 30 Dec 2019
Greinert A (2015) The heterogeneity of urban soils in the light of their properties. J Soils Sediments 15:1725-1737. https://doi.org/10. 1007/s11368-014-1054-6

Grenzius R (1987) Die Böden berlins (west) - Klassifizierung, Vergesellschaftung, ökologische Eigenschaften. Dissertation, Technische Universität Berlin

Grenzius R (1993) Conception soil maps for urban areas. Z Pflanzenernähr Bodenkd 156(3):209-212. https://doi.org/10.1002/ jpln.19931560304

Grenzius R, Blume HP (1983) Aufbau und ökologische Auswertung der Bodengesellschaftskarte Berlin. Mitt Dtsch Bodenkdl Ges 36:57-62 https://www.dbges.de/de/system/files/mitteilungen_dbg/ Mitteilungen-der-DBG-1983_36.pdf. Accessed 11 Aug 2020

Hiller DA, Meuser H (1998) Urbane Böden. Springer, Berlin

Holland K (1996) Stadtböden im Keuperland am Beispiel Stuttgarts. Dissertation, Universität Hohenheim

Hollis JM (1991) The classification of soils in urban areas. In: Bullock P, Gregory PJ (eds) Soils in the urban environment. Blackwell, Oxford, pp 5-27. https://doi.org/10.1002/9781444310603.ch2

IUSS Working group WRB (2006) World reference base for soil resources 2006 - a framework for international classification, correlation and communication, world soil resources report no. 103, food and agricultural Organization of the United Nations, Rome

IUSS Working group WRB (2015) World reference base for soil resources 2014, update 2015 - international soil classification system for naming soils and creating legends for soil maps, world soil resources report no. 106, food and agricultural Organization of the United Nations, Rome

Kabała C, Charzyński P, Chodorowski J, Drewnik M, Glina B, Greinert A, Hulisz P, Jankowski M, Jonczak J, Łabaz B, Łachacz A, Marzec M, Mendyk Ł, Musiał P, Musielok Ł, Smreczak B, Sowiński P, Świtoniak M, Uzarowicz Ł, Waroszewski J (2019) Polish soil classification, $6^{\text {th }}$ edition - principles, classification scheme and correlations. Soil Sci Annu 70(2):71-97. https://doi.org/10.2478/ssa-20190009

Kojima R (1996) Introduction: population migration and urbanization in developing countries. Dev Econ 34(4):349-369. https://doi.org/10. 1111/j.1746-1049.1996.tb01176.x

Lehmann A, Stahr K (2007) Nature and significance of anthropogenic urban soils. J Soils Sediments 7(4):247-260. https://doi.org/10. $1065 /$ jss2007.06.235

Makki M (2013) Berliner Böden - Genese und Funktionen. Geogr Rundsch 02(2013):46-51

Makki M (2015a) Böden einer Metropole - Herrscht Chaos im Berliner Untergrund? In: Makki M, Kleßen R (eds) Exkursionsführer zum Deutschen Kongress für Geographie 2015. Stadt land Schaf(f)t land Schaf(f)t Stadt, Herausforderungen von mensch-UmweltBeziehungen im 21. Jahrhundert, Geographisches Institut, Humboldt-Universität zu Berlin, pp. 22-30

Makki M (2015b) Pedodiversität einer Metropole, Entwicklung und Verbreitung der Berliner Stadtböden. In: STANDORT - Z Angew Geogr 39(2):69-76 https://doi.org/10.1007/s00548-015-0377-x

Makki M, Köhler P (eds) (2013) Rapidly growing cities in Iran and its geoecological challenges using the city of Arak. Berl Geogr Arb 119, Humboldt-Universität zu Berlin

Makki M, Thestorf K (2015) Berliner bauen ihre eigenen Berge. In: Makki M, Kleßen R (eds) Exkursionsführer zum Deutschen Kongress für Geographie 2015, „Stadt land Schaf(f)t - land Schaf(f)t Stadt"-Herausforderungen von mensch-UmweltBeziehungen im 21. Jahrhundert, Geographisches Institut, Humboldt-Universität zu Berlin, pp. 258-262

Makki M, Edelmann S, Kinlechner V (2014) Bodenkundliche Kartierung und Analysen im Untersuchungsgebiet „Berlin - Lichterfelde Süd“, Technical Report, Berlin 
Makowsky L, Meuser H (2007) Quantification of carbon content in soils from abandoned contaminated land dominated by technogenic substrates. Altlasten spektrum 2/2007:53-60

Makowsky L, Höke S, Kneib WD, Kocher B, Lehmann A, Steinweg B, Burghardt W (2019) 30 Jahre Arbeitsgruppe urbane Böden/ Arbeitskreis Stadtböden. Eine junge geschichte zu den urbanen Böden unter unseren Füßen. Bodenschutz 24(2):48-56

McDonnell MJ, Pickett STA (1990) Ecosystem structure and function along urban-rural gradients ecology: an unexploited opportunity for ecology. Ecology 71(4):1232-1237. https://doi.org/10.2307/ 1938259

Mekiffer B (2008) Eigenschaften urbaner Böden berlins - statistische Auswertung von Gutachtendaten und Fallbeispiele. Dissertation, Technische Universität Berlin

Meuser H. (1996a) Technogene substrate als Ausgangsgestein der Böden urban-industrieller Verdichtungsräume - dargestellt am Beispiel der Stadt Essen. Habilitation, Christian-Albrechts-Universität Kiel

Meuser H (1996b) Schadstoffpotential technogener substrate in Böden urban-industrieller Verdichtungsräume. Z Pflanzenernähr Bodenkd 159(6):621-628

Meuser H (2002) Anthropogene Gesteine. In: Blume HP, FelixHenningsen P, Fischer WR, Frede HG, Horn R, Stahr K (eds) Handbuch der Bodenkunde. Ecomed, Landsberg

Meuser H (2010) Contaminated urban soils. Env poll 18, springer, Dordrecht

Meuser H, Konen L (eds) (2011) Katalog technogener substrate Abbildungen, Eigenschaften, Gefährdungspotential, Hochschule Osnabrück, Fakultät Agrarwissenschaften und Landschaftsarchitektur, Studiengang Bodennutzung und Bodenschutz

Meuser H, Schleuß U, Taubner H, Wu Q (1998) Bodenmerkmale urbanindustrieller Standorte in Essen. Z Pflanzenernähr Bodenkd 161(3): 197-203

Morel JL, Chenu C, Lorenz K (2015) Ecosystem services provided by soils of urban, industrial, traffic, mining, and military areas (SUITMAs). J Soils Sediments 15(8):1659-1666. https://doi.org/ 10.1007/s11368-014-0926-0

New York City Soil Survey Staff (2005) New York City reconnaissance soil survey. United States department of agriculture. Natural Resources Conservation Service, Staten Island

Pouyat RV, Yesilionis ID, Russell-Anelli J, Neerchal NK (2007) Soil chemical and physical properties that differentiate urban land-use and cover types. Soil Sci Am J 71:1010-1019. https://doi.org/10. 2136/sssaj2006.0164

Richter S, Haase D, Thestorf K, Makki M (2020) Carbon pools of Berlin, Germany: organic carbon in soils and aboveground in trees. Urban For Urban Green 54:126777. https://doi.org/10.1016/j.ufug.2020.126777

Runge M (1975) West-Berliner Böden anthropogener Litho- oder Pedogenese. Dissertation, Technische Universität Berlin

Sauerwein M (2004) Urbane Bodenlandschaften - Eigenschaften, Funktionen und Stoffhaushalt der siedlungsbeeinflussten Pedosphäre im Geoökosystem. Habilitation, Martin-LutherUniversität Halle

Schad P (2018) Technosols in the world reference base for soil resources history and definitions. Soil Sci Plant Nutr 64(2):138-144. https:// doi.org/10.1080/00380768.2018.1432973

Schneider J, Makowsky L (2017) Urban soil surveys - the case of Germany. In: Levin MJ, John Kim KH, Morel JL, Burghardt W, Charzynski P, Shaw RJ, IUSS Working Group SUITMA (eds) Soils within cities, global approaches to their sustainable management composition, properties, and functions of soils of the urban environment. Schweizerbart, Stuttgart, pp 113-123

Senate Department for the Environment, Transport and Climate Protection (ed) (2017a) Landscape Programme. https://www.berlin.de/senuvk/ umwelt/landschaftsplanung/lapro/. Accessed 19 Dec 2019

Senate Department for the Environment, Transport and Climate Protection (2017b) Merkblatt zur Verhaltensweise beim Auffinden von Boden- und Grundwasserverunreinigungen (Stand 10/2017), www.berlin.de/senuvk/umwelt/bodenschutz/de/fragen/download/ merkblatt.pdf. Accessed 30 Dec 2019

Senate Department for the Environment, Transport and Climate Protection (ed) (2018a) Berlin Environmental Atlas / 01.01 Soil Associations (Edition 2018). http://www.stadtentwicklung.berlin. de/umwelt/umweltatlas/eid101.htm. Accessed 19 Dec 2019

Senate Department for the Environment, Transport and Climate Protection (ed) (2018b) Berlin Environmental Atlas / 01.13 Planning Advice for Soil Protection (2018 edition). http://www. stadtentwicklung.berlin.de/umwelt/umweltatlas/eic113.htm Accessed 19 Dec 2019

Senate Department for the Environment, Transport and Climate Protection (ed) (2018c) Berlin Environmental Atlas / 01.06 SoilScientific Characteristic Values (Edition 2018). https://www. stadtentwicklung.berlin.de/umwelt/umweltatlas/eid106.htm. Accessed 22 June 2020

Senate Department for Urban Development and Housing (ed) (2016a) Berlin Environmental Atlas / 06.07 / 08 Urban Structure / Urban Structure - Area Types differentiated (Edition 2016), http://www. stadtentwicklung.berlin.de/umwelt/umweltatlas/edin_607.htm. Accessed 19 Dec 2019

Senate Department for Urban Development and Housing (ed) (2016b) Straßenbaum-Zustandsbericht Berliner Innenstadt 2015, https:// www.berlin.de/senuvk/umwelt/stadtgruen/stadtbaeume/downloads/ strb_zustandsbericht2015.pdf. Accessed 16 June 2020

Senate Department for Urban Development and Housing (2017): Berlin Environmental Atlas / 01.02 Impervious Soil Coverage (Edition 2017). http://www.stadtentwicklung.berlin.de/umwelt/umweltatlas/ edin_102.htm. Accessed 19 Dec 2019

Senate Department for Urban Development and Housing (2020a): Berlin Environmental Atlas / 04 Climate. https:// www.stadtentwicklung.berlin.de/umwelt/umweltatlas/ edinh_04.htm. Accessed 16 June 2020

Senate Department for Urban Development and Housing (ed) (2020b) Land Use Planning. https://www.stadtentwicklung.berlin.de/planen/ fnp/en/fnp/index.shtml. Accessed 07 Aug 2020

Stasch D, Stahr K, Sydow M (1991) Welche Böden müssen für den Naturschutz erhalten warden? Berl Naturschutzblätter 35(2):53-64

Stroganova M, Prokofieva, T (2002) Urban soils classification for Russian cities of the taiga zone. In: Micheli E, Nachtergaele FO, Jones RJA, Montanarella L (eds) Soil Classification 2001. European soil bureau research report, 7, EUR 20398 EN, Office for Official Publications of the European Communities, Luxembourg, pp. 153-156

Sukopp H, Bennert W, Blume HP, Böcker R (1970) Das Naturschutzgebiet Pechsee - wissenschaftliche Grundlagenuntersuchungen in Berliner Natur- und Landschaftsschutzgebieten. Technische Universität Berlin, Berlin

United Nations, Department of Economic and Social Affairs, Population Division (2019) World urbanization prospects: the 2018 revision (ST/ESA/SER.A/420). United nations, New York

Wang LY, Xiao Y, Rao EM, Jiang L, Xiao Y, Ouyang ZY (2018) An assessment of the impact of urbanization on soil erosion in Inner Mongolia. Int J Environ Res Public Health 15/3:550. https://doi.org/ 10.3390/ijerph 15030550

Wessolek G (2001) Bodenüberformung und -versiegelung. In: Blume HP, Felix-Henningsen P, Fischer WR, Frede HG, Horn R, Stahr K (eds) Handbuch der Bodenkunde. ecomed, Landsberg

Wessolek G (2008) Sealing of soils. In: Marzluff JM et al (eds) Urban ecology. Springer, Boston, pp 161-179. https://doi.org/10.1007/ 978-0-387-73412-5 10

Publisher's note Springer Nature remains neutral with regard to jurisdictional claims in published maps and institutional affiliations. 